UDC 378.018.4: 37

DOI https://doi.org/10.32840/1992-5786.2021.79.1.23

I. V. Kolyada

Lecturer at the Foreign Languages Department National University of Pharmacy

S. V. Zhurkina

Lecturer at the Foreign Languages Department National University of Pharmacy

O. O. Chernyshenko

Candidate of Pedagogical Sciences, Lecturer at the Foreign Languages Department National University of Pharmacy

\title{
ORGANIZATION OF BLENDED LEARNING AT THE CURRENT STAGE OF HIGHER EDUCATION DEVELOPMENT
}

The main approaches for the organization of educational activities of students on the basis of blended learning have been scrutinized in the article. As a result of the pandemic, university education around the world is being restructured, and blended (hybrid) education is becoming the new norm. It is time to think about a more thoughtful approach to implementing effective blended learning. Organizations are reaching for the new norm precisely because it works and can help in case of future failures. Blended learning is a combination of traditional forms of classroom training with elements of e-learning, which uses special information technologies such as computer graphics, audio and video, interactive elements, etc. It should be noted that the learning process in blended learning is a sequence of phases of traditional and e-learning, which alternate over time. The article notes the relevance of this approach to learning, as it allows you to take advantage of the flexibility and convenience of distance learning and the benefits of traditional forms of learning. Some features of blended learning have been identified in the research, and the main one is that blended learning is a purposeful process of acquiring knowledge, skills and abilities within certain disciplines, part of which is implemented remotely. The Ministry of Education and Science of Ukraine has developed recommendations for the organization of blended learning in higher education institutions. The recommendations include advice on how to organize blended learning, how to choose regulations and technology base, train staff and plan the learning process. Learners can benefit from using a blended learning strategy. This is due to the fact that the combination of learning approaches used in the blended program can stimulate their interest and increase their involvement, thereby increasing their effectiveness. Thus, blended learning is a model that combines technology to accelerate learning and increase its effectiveness.

Key words: teaching methods, blended learning, learning management system, distance learning, e-learning platforms, methodical recommendations.

Formulation of the problem. Today, in response to the challenges facing education (development of IT technologies, their use in the educational process, the introduction of distance learning, activation of independent cognitive activity of students), the educational community solves the problem of organizing such training that would meet the challenges. The introduction of modern technologies in education creates new opportunities for the implementation of the task, intensifies the independent cognitive activity of students, ensures the quality of higher education. That is why one of the promising areas of higher education is considered to be blended learning. The use of blended learning technologies is a new type of organization of the educational process, which has raised many problems of teachers and administration of higher education institutions selection of tools for work; organization of distance learning; assessment of students and control over their educational and cognitive activities; development or selection of a blended learning model; establishing effective interaction of all participants in the educational process; ensuring the quality of education.

Analysis of recent research and publications. Such researchers as K. Bugaychuk, O. Korotun, O. Krivonos, V. Kukharenko, S. Berezenska, A. Fandeyeva, O. Kuzmenko study the problem of blended learning in the education system. Blended learning issues have been also scrutinized by some foreign researchers, such as B. Means, Y. Toyama, R. Murphy, E. Werth, L. Werth, E. Kellerer, A. Alammary, J. Sheard, A. Carbone. However, the theory of using blended learning in the institutions of higher education needs further studies. That is why there is a need to find new ways to develop teacher education that can help adapt the learning process 
to modern challenges. This includes the introduction of blended learning, which will help to intensify the independent cognitive activity of students studying in pedagogical specialties.

The purpose of the article. The main purpose of the study is to analyze views on the essence of blended learning and its tasks in the educational process of higher education institutions, as well as to determine the prospects for its application in the practice of institutions of higher education. The study was conducted in 2020-2021. The following research methods have been considered: theoretical analysis of normative documents, psychological, pedagogical and methodological literature, which generalize modern innovative integrated methodological approaches to the development of blended learning.

Presenting the main material. Blended (or hybrid) learning is the integration of online learning with traditional learning in the classroom. Such blended learning involves the use of two or more different teaching methods, such as alternating face-toface classes with online learning.

To understand clearly the potential of the method, terminological differentiation has been studied. Foreign experts (e.g. B. Means, Y. Toyama, R. Murphy, E. Werth, L. Werth, E. Kellerer, A. Alammary, J. Sheard, A. Carbone) consider blended learning as:

- a set of technologies and traditional learning in the classroom, based on a flexible approach that takes into account the benefits of learning and control tasks in the network, which can significantly improve the quality of learning while reducing the cost of learning space [9];

- a set of educational processes provided by personal communication and software technologies within a single educational space [7];

- a course of study that combines personal communication and the use of technology [8].

$\mathrm{K}$. Bugaychuk identifies the following signs of blended learning:

- blended learning refers to formal learning within the activities of educational institutions; - it is a purposeful process of acquiring knowledge, skills and abilities within certain academic disciplines, part of which is implemented remotely;

- ICT and Technical Teaching Aids (PCs, mobile phones, tablets, projectors, etc.) are used during the study of the discipline;

- ICTs are used not only for storage and delivery of educational material, but also for the implementation of control measures, the organization of educational interaction (consultations, discussions); - there is a control of the student over the time, place, routes and pace of study [1].

Ukrainian researcher V. Kukharenko among the trends in higher education identifies the spread of blended learning in higher education institutions [3]. In his studies the following trends have been iden- tified: macro-trends (emergence of new skills and competencies, demographic change, globalization); mesotrends (popularity of non-formal learning, education reform, formal and non-formal learning flow into each other); and micro-trends (recognition of non-formal learning, tendency to provide different levels of learning context for representatives of different generations, attention to the development of competencies, increasing the number of generation $Y$ in the workforce and the corresponding changes in both academic and corporate training, uneven use of technology in the learning process by representatives of different generations).

According to A. Fandeyeva a mixed approach to learning is one of the most relevant educational technologies today, as it allows you to take advantage of the flexibility and convenience of distance learning and the benefits of traditional learning [5]. Blended learning methods do not exclude useful methods and principles of the traditional education system, but, on the contrary, improve and supplement its capabilities.

Foreign researchers B. Means, Y. Toyama, R. Murphy studied the problem of implementing blended learning and found that teachers who have experience of blended learning, found its benefits, because blended learning allows students to organize their own learning, blended learning funds provide resources to students who missed classes, provide feedback and differentiated learning. Teachers noted that the use of blended learning motivates them to be opentoinnovation, helpstomonitorstudentlearning[9].

A. Alammary, J. Sheard, A. Carbone in their study distinguish three different levels of organization of blended learning: with low, medium and high degrees of influence [8]. This classification is compiled according to the potential for change in the existing curriculum and student learning experience. The main advice to teachers is that those who do not have experience in blended learning should start with a small impact. Those who already have some experience can move on to medium impact. And those who have enough confidence, knowledge and experience in blended learning can try the third level.

The main difference between blended learning and the regular system is the active use of IT technologies to prepare students for practical and seminar classes, independent work and independent cognitive activity. Technology is becoming a full part of the learning process. During the application of blended learning the following changes occur:

- students calculate their own time, which increases the effectiveness of learning;

- teachers focus on non-cognitive skills (communication, self-identification, teamwork, etc.) and the formation of students' worldview;

- one day a week students work independently, and teachers conduct short 10-minute individual tests for each student. 
Blended learning, on the one hand, makes it possible to organize time most efficiently. It is not only a combination of certain formal learning tools (working in the classroom, studying and repeating material) with non-formal (discussing important aspects of learning material via e-mail, Internet platforms and online conferences), but a combination of different tools for the presentation of educational material (fulltime, distance and self-study).

In order to organize successfully independent educational and cognitive activities of students in a mixed form of education, a multimedia system of e-learning has been organized. This system can work in real time, it is characterized by a high level of interactivity, contains a huge number of individual and group tasks. The operation of this system is provided by the electronic platform Moodle [6] (online learning platform), which can be used to create a rich information environment and conditions for active study of disciplines. The Moodle (Modular ObjectOriented Dynamic Learning Environment) platform is designed to bring educators, administrators, and students together in one robust, secure, and integrated system to create a personalized learning environment. This platform contains a large number of different learning elements (so-called modules) that provide dialogue and cooperation between teacher and students. With the help of the platform, the teacher can choose any of the modules, place it on the site, edit, update, use to inform, teach and evaluate students. The platform allows to use forums within the discipline, monitor student activity, contains a userfriendly electronic register. Particular attention in the work on this platform is paid to the organization of independent work of students. Students are offered tasks for independent work, resources for work (literature, electronic resources, videos on the topic, files necessary for work are fixed). During the work, students have the opportunity to communicate on the forum with each other, as well as to receive advice from the teacher. Among the advantages of blended learning are the following:

- a wide selection of quality courses;

- flexibility in planning independent educational and cognitive activities of students;

- involvement of the best teachers in the educational process of the teacher and the student,

- it makes the learning process more interesting.

Conclusions and prospects for further research. Thus, analysis of views on the essence of blended learning and its tasks in the educational process of higher education institutions shows that the organization of blended learning is a complex, multifaceted problem. The introduction of blended learning technology in the educational process activates the independent cognitive activity of students, as well as ensures the quality of higher education. So, blended learning is one of the promising areas of higher education in Ukraine. A promising area of blended learning is the integration of online learning with traditional learning. The main tool for working in a blended learning environment is the active use of IT technologies to organize independent cognitive activity of students. The organization of distance learning involves the use of electronic platforms. Assessment of students and control over their educational and cognitive activities is due to both direct communication of students with the teacher and through the use of electronic technologies, which significantly accelerates the process of checking tasks for independent educational and cognitive activities of students. The blended learning model includes alternating online and offline parts according to a specific schedule or teacher's recommendations. These parts can include work in both subgroups and the whole group, group projects, presentations, individual work with the teacher and written assignments. Establishing effective interaction of all participants in the educational process makes it possible to ensure the quality of higher education. A promising direction in the development of blended learning is the development of an in-depth virtual model, according to which students independently divide courses into online and offline. This model of "independent mixing" involves a high level of skills of self-organization and activity of students, which activates their independent cognitive activity. The advantage of this model is the flexibility of schedule and load distribution. The model of blended learning provides for the organization of advanced classes, which does not require additional facilities, laboratories, and this is an advantage for higher education institutions.

\section{References:}

1. Бугайчук К. Змішане навчання: теоретичний аналіз та стратегія впровадження в освітній процес вищих навчальних закладів. Інфрормаційні технології $і$ засоби навчання. 2016. T. 54. № 4.

2. Коротун О., Кривонос О. Змішане навчання як основа формування ІКТ-компетентності вчителя. Наукові записки. Вип. 8(11).

3. Теорія та практика змішаного навчання : монографія / В.М. Кухаренко та ін. ; за ред. В.М. Кухаренка. Харків : Міськдрук, НТУ «ХП|», 2016. 284 с.

4. Кузменко О. Змішане навчання як інноваційна форма організації навчального процесу в школі. Наукові записки Тернопільського національного педагогічного університету імені Володимира Гнатюка. Серія «Педагогіка». 2017. № 3. URL: http://nzp.tnpu.edu.ua/article/ view/120142.

5. Фандєєва А.Є. Змішане навчання як технологія змін і трансформації. Народна освіта. 2017. № 2(32).

6. Moodle. URL: https://moodle.org. 
7. Eric Werth, Ed.D., Lori Werth, Ph.D., Eric Kellerer, Ed.D.Transforming K-12 Rural Education through Blended Learning: Barriers and Promising Practices. Northwest Nazarene University Doceo Center for Innovation in Teaching and Learning. URL: https://files.eric.ed.gov.

8. Ali Alammary, Judy Sheard, Angela Carbone. Blended learning in higher education: Three

$\begin{array}{lll}\text { different design } & \begin{array}{c}\text { approaches. } \\ \text { Journal of }\end{array} \text { Australasian } \\ \text { 2014. № 30(4). } & & \text { Technology. }\end{array}$

9. Means B., Toyama Y., Murphy R., Bakia, M., \& Jones, K. (2010, September). Evaluation of Evidence-Based Practices in Online Learning: A Meta-Analysis and Review of Online Learning Studies.

\footnotetext{
Коляда І. В., Журкіна С. В., Чернишенко О. О. Організація змішаного навчання на сучасному етапі розвитку вищої освіти

У статті розглядаються основні підходи для організації навчальної діяльності студентів на основі змішаного навчання (ЗН). У результаті пандемії навчання у ВНЗ по всьому світі перебудовується, і змішане (дібридне) навчання стає новою нормою. Прийшов час подумати про більш продуманий підхід до впровадження ефрективного змішаного навчання. Організації тягнуться до нової нормі саме тому, що вона працює і може допомогти в разі майбутніх збоїв. Змішане навчання (англ. "Blended Learning") - це поєднання традиційних фрорм аудиторного навчання з елементами електронного навчання, в якому використовуються спеціальні інфоормаційні технології, такі як комп'ютерна графріка, аудіо та відео, інтерактивні елементи тощо. Необхідно зазначити, що навчальний процес при змішаному навчанні являє собою послідовність фраз традиційного та електронного навчання, які чергуються в часі. У цій статі ми підкреслюємо, наскільки актуальним є цей підхід у навчанні у вищих навчальних закладах. Ми маємо на увазі той факт, що змішане навчання поєднує у собі гнучкість дистанційного навчання та важливі методи традиційного навчання. Ми визначили головні ознаки змішаного навчання у цій статmі. Міністерство освіти і науки розробило рекомендації з організації змішаного навчання в закладах вищої освіти. Рекомендації містять поради, як організувати змішане навчання, як вибрати нормативне забезпечення та технологічну базу, підготувати персонал і спланувати навчальний процес. Ti, що навчаються, можуть отримати вигоду з використання стратегії змішаного навчання. Це пов'язано з тим, що поєднання підходів до навчання, що використовуються у змішаній програмі, може стимулювати їх інтерес і збільшити їх залученість, тим самим підвищуючи їх ефективність. Таким чином, змішане навчання являє собою модель, яка об'єднує технології для прискорення навчання і підвищення його ефективності.
}

Ключові слова: методи навчання, змішане навчання, система управління навчанням, дистанційне навчання, платформи електронного навчання, методичні рекомендації. 